\title{
Performance of agronomical and seed biochemical traits of soybean genotypes in relation to their tolerance and preference by Nezara viridula
}

\author{
HERU KUSWANTORO ${ }^{1 \bullet}$, ERLIANA GINTING ${ }^{1}$, JOKO SUSILO UTOMO ${ }^{1}$, ERIYANTO YUSNAWAN ${ }^{1}$ \\ ${ }^{1}$ Indonesian Legume and Tuber Crops Research Institute. Jl. Raya Kendalpayak Km. 8, Pakishaji, Malang 65162, East Java, Indonesua. Tel. +62-341- \\ 801468, Fax. +62-341-801496, `email: herukusw@gmail.com
}

Manuscript received: 3 December 2018. Revision accepted: 14 January 2019.

\begin{abstract}
Kuswantoro H, Ginting E, Utomo JS, Yusnawan E. 2019. Performance of agronomical and seed biochemical traits of soybean genotypes in relation to their tolerance to and preference by Nezara viridula. Biodiversitas 20: 356-363. Qualitative and quantitative variations of biochemical compounds in plant organs is one of the causes leading to infestation by a certain pest which prefers to feed on particular genotypes than other genotypes. Objectives of this study is to find out the relationship of selected agronomical features and seed biochemical contents of soybean genotypes with their tolerance to Nezara viridula and also the preference of $N$. viridula to these genotypes. A total of 50 soybean germplasm were grown at Muneng research station during the dry season of 2016. The variability of the tested germplasm was reflected in the diversity of agronomic characters and seed biochemical contents. There was a significant positive correlation among the studied seed biochemical parameters, namely protein, methionine and cysteine contents. The protein and cysteine contents did not relate to $N$. viridula preference, but it was related to soybean tolerance against $N$. viridula. It was indicated by the insignificant positive correlation of protein and cysteine contents with the number of unfilled pods and the negative correlation of protein and cysteine contents with the ratio of number of unfilled pods to the total number of pods. Methionine content increased $N$. viridula preference, but it had no effect on soybean tolerance. Five genotypes, namely MLGG 0164, MLGG 0195, MLGG 0103, MLGG 0896 and MLGG 0196 were selected based on high seed biochemical contents which can be used as gene sources in soybean breeding programs. Among these five genotypes, MLGG 0195 had high protein, methionine and cysteine contents, but it was not tolerant to $N$. viridula. Hence, this genotype should be cultivated by controlling $N$. viridula optimally. MLGG 0196 had the highest methionine content, relatively high cysteine content, and $N$. viridula tolerance. This genotype can be used to improve seed biochemical content and plant tolerance against $N$. viridula.
\end{abstract}

Keywords: cysteine, methionine, Nezara viridula, pest preference, protein, soybean, host tolerance

\section{INTRODUCTION}

Soybean (Glycine $\max$ (L.) Merr.) has a strategic position in food security as a source of protein and functional, high quality food ingredients for human needs. Soybean is an important source of vegetable food material with $35-45 \%$ protein content and it plays an important role in various aspects of the economy in Indonesia. Major share of soybean produced in Indonesia is used as food while the rest is used as animal feed and seed. Indonesia's soybean consumption is $7.13 \mathrm{~kg}$ per capita per year (Ministry of Agriculture 2015). The highest consumption is in the preparation of traditional tofu and tempeh which is $0.144 \mathrm{~kg}$ and $0.134 \mathrm{~kg}$ per capita per week, respectively. This is even higher than the consumption of beef which is $0.008 \mathrm{~kg}$ per capita per week (BPS 2017). The consumption of tofu and tempeh is higher than beef because of the lower price of tofu and tempeh than beef. Therefore, soybean is a valuable protein source for Indonesian people allowing replacement of beef protein.

Besides protein, soybean also contains many amino acids. Two of those amino acids are methionine and cysteine. However, the availability of methionine and cysteine is very limited (Gupta et al. 2010). These amino acids are necessary because of their linkage to many diseases such as Alzheimer, cardiovascular and diabetes (Ball et al. 2016). The functions of cysteine and methionine are similar-they serve as cellular antioxidants and protein's structure stabilizer (Kim et al. 2014). The human immune system can be stimulated by natural diet ingredients involving amino acids (Wu 2013). Addition of cysteine and methionine in a natural diet can improve human health and avoid certain diseases.

Differences in plant resistance to certain insects are often due to the chemical factors present in those plants, both qualitatively and quantitatively. Biochemical factors in plants, especially toxic alkaloids (Ge et al. 2015), can inhibit the physiological processes of the insects. The lack of one or more of the substances required by the insects, such as protein (Moreno et al. 2011) and amino acids (Karley et al. 2002), also inhibits insect metabolism and influence insect life. Proteins are needed for growth and development of insects. The quality of proteins depends on the amino acids and the requirement of protein and amino acids varies from insect to insect. However, the presence of some proteins may also have negative impact on the insects (Minney et al. 1990; Ryan 1990; Hartweck et al. 1997). 
Nezara viridula (Linnaeus, 1758), commonly known as the southern green stink bug, is one of the insect pests feeding on plant organs, especially immature soybean pods. Many studies regarding the preference of $N$. viridula to plant characteristics have been reported. However, studies on preference of $N$. viridula to the biochemical contents of soybean seeds are very limited. Therefore, we have studied the protein, methionine and cysteine contents of soybean seeds in relation to $N$. viridula preference and soybean tolerance.

\section{MATERIALS AND METHODS}

\section{Study sites}

The field studies with soybean plants were conducted at Muneng Research Station which is located in Muneng Kidul Village, Sumberasih Sub-district, Probolinggo District, East Java Province, Indonesia. It's geographical co-ordinate are $7^{\circ} 48^{\prime} 06.9^{\prime \prime} \mathrm{S}$ and $113^{\circ} 09^{\prime} 37.2^{\prime \prime} \mathrm{E}$, and the altitude is $54 \mathrm{~m}$ above sea level. Protein content of seeds was studied at Food laboratory of Indonesian Legume and Tuber Crops Research Institute (Malang Regency, East Java Province, Indonesia; $8^{\circ} 2^{\prime} 50.063 " \mathrm{~S}$ and $112^{\circ} 37^{\prime 24}$.092" E), and methionine and cysteine contents were analysed at Saraswanty Laboratory (Bogor City, West Java Province, Indonesia; 6³3'23.649" S and 106 ${ }^{\circ} 46^{\prime} 12.579^{\prime \prime}$ E).

\section{Plant materials}

Fifty types of soybean germplasm were used as planting materials which includes Indonesian landraces and introduced accessions. The Indonesian landraces were originated from various islands of Indonesia, while the introduced accessions were from other countries.

\section{Experimental Design and planting}

The planting experiment was conducted as randomized complete block design with three replications. Planting was done in $40 \mathrm{~cm} \times 15 \mathrm{~cm}$ planting space. Each genotype was planted in two rows of $3 \mathrm{~m}$ length. Fertilization was provided in the form of $50 \mathrm{~kg} \mathrm{ha}^{-1}$ of Urea, $75 \mathrm{~kg} \mathrm{ha}^{-1}$ of SP36, and $75 \mathrm{~kg} \mathrm{ha}^{-1}$ of $\mathrm{KCl}$. To prevent seedling fly pest, seeds were treated with $12.5 \mathrm{~g}$ carbosulfan for every $1 \mathrm{~kg}$ seed. Weeding was performed at an interval of every three weeks (3rd, 6th and 9th weeks), after planting.

\section{Pest infestation}

Infestation of soybean plants with $N$. viridula was carried out naturally by growing infested soybean plants for 40 days around the planting plots. At the time of pod filling, the infestation plants were harvested so that $N$. viridula moved to the test plants and infested them.

\section{Agronomical characters, pest preference and plant tolerance observation}

Nezara viridula preference and plant tolerance was analysed by observing certain agronomical characters of soybean such as total number of pods, number of unfilled pods, weight of 100 seeds and seed weight per plant.
Preference of $N$. viridula is indicated mainly by number of unfilled pods, based on the assumption that soybean genotypes having more number of unfilled pods are more favorable genotypes for $N$. viridula. Plant tolerance to $N$. viridula was measured by the ratio of the number of unfilled pods to total number of pods. A higher ratio is indicative of lower tolerance and vice versa.

\section{Protein analysis}

The protein content of the fifty genotypes studied was measured using the Mikro Kjeldhal method (AOAC 2005). The seed sample was digested with concentrated $\mathrm{H}_{2} \mathrm{SO}_{4}$ prior to distillation, the destilate is treated with boric acid and subsequently titrated against a $\mathrm{HCl}$. A blank (without sample) was also prepared and subjected to the entire procedure. The titrate volume was used to calculate the total Nitrogen and protein content. The calculation was done by multiplying the $\% \mathrm{~N}$ with a conversion factor of 5.75 .

\section{Methionine and cysteine analysis}

Methionine and cysteine content of 20 genotypes which represent low, medium and high protein genotypes were estimated by using AccQ Tag UPLC method, according to Rohman and Gandjar (2007) and Waters System Guide (2012).

\section{RESULTS AND DISCUSION}

\section{Performance of some agronomical and chemical characters}

The effect of $N$. viridula infestation on studied agronomical characters of 50 soybean germplasms is shown in Fig. 1. Number of filled pods per plant ranged from $5.8-82.0$, with a mean of 28.5 pods. This was lower than the number of unfilled pods per plant for which the mean was 43.7 pods per plant. Although the mean value for the number of filled pods was lower than that for number of unfilled pods, the standard deviation for number of filled pods was higher. The high standard deviation indicated a broad variability. The broad variability may be due to the fact that the plant materials used in this study originated from various regions of Indonesia and also from abroad.

The number of total pods in this study ranged from 42114 pods per plant and the mean value was 72 pods (Fig. 2). Usually, in plants under normal conditions without pest infestation, the number of unfilled pods was very low and could be ignored. Similar results were reported in studies related to the effect of environment stresses, such as waterlogging and acidic dryland, which produced maximum of 3 unfilled pods with the mean value of 1.47 pods (Kuswantoro 2015) and 6 pods with the mean of 3 pods (Kuswantoro 2016), respectively. The number of total pods illustrated the maximum potential for the number of filled pods. This potential may be lower than the true potential number of total pods because some pods may have fallen due to the $N$. viridula infestation. In this study, number of fallen pods was not noted. In the normal condition, Malek et al. (2014) obtained an average of 48.13 
total pods per plant which was much lower than the value obtained during the present experiment.

The ratio of number of unfilled pods per plant to the number of total pods is an indication of the plant tolerance against $N$. viridula. Infested plants producing a large number of total pods are having a higher tolerance than those plants producing comparatively less number of total pods. Plant tolerance differs from the pest preference where the number of unfilled pods indicates that a genotype is prefered by the pest. In soybean germplasms viz., MLGG 0564, MLGG 0879, MLGG 0196, and MLGG 0892, the ratio obtained was $0.22,0.31,0.37$ and 0.38 , respectively. These four soybean genotypes had the highest tolerance value than others.

The weight of 100 seeds in this study was also very diverse, which ranged from 8.02 to 20.11 g. Majority of seed sample weights were in the range of 14-16 g/100 seeds (Fig. 3). Some genotypes showed seed size greater than $16 \mathrm{~g} / 100$ seeds. These genotypes could be used as a source of genes for improvement in seed size. Kuswantoro (2017) also reported a wide genetic diversity in soybean seed size. $N$. viridula feeds on developing seeds causing yield reduction. Some protein kinases are involved in tolerance response when a developing seed is fed by the pest (Giacometti 2016).

Seed yield ranged from $0.66-11.45 \mathrm{~g} /$ plant with a mean of $4.32 \mathrm{~g}$ per plant (Fig. 3). The highest number of genotypes are in the class of $3 \mathrm{~g}$ plant $^{-1}$ seed yield, followed by the class of $5 \mathrm{~g}$ plant $^{-1}$. Based on the distribution of the seed yield, it may be opined that the tested germplasms have a broad variability with respect to this character also, as reported earlier by Kuswantoro (2017). Naik et al. (2016) also reported a high coefficient of genetic diversity regarding seed yield per plant. In the present study, two genotypes were found to be producing seed yield of about $11 \mathrm{~g} \mathrm{plant}^{-1}$, namely MLGG 0564 (11.45 g) and MLGG 0196 (10.95 g). These two are prospective genotypes which may be further used for improving soybean seed yield. The seed yields of these two genotypes are higher than the highest seed yield in normal conditions, as reported by Islam et al. (2016).
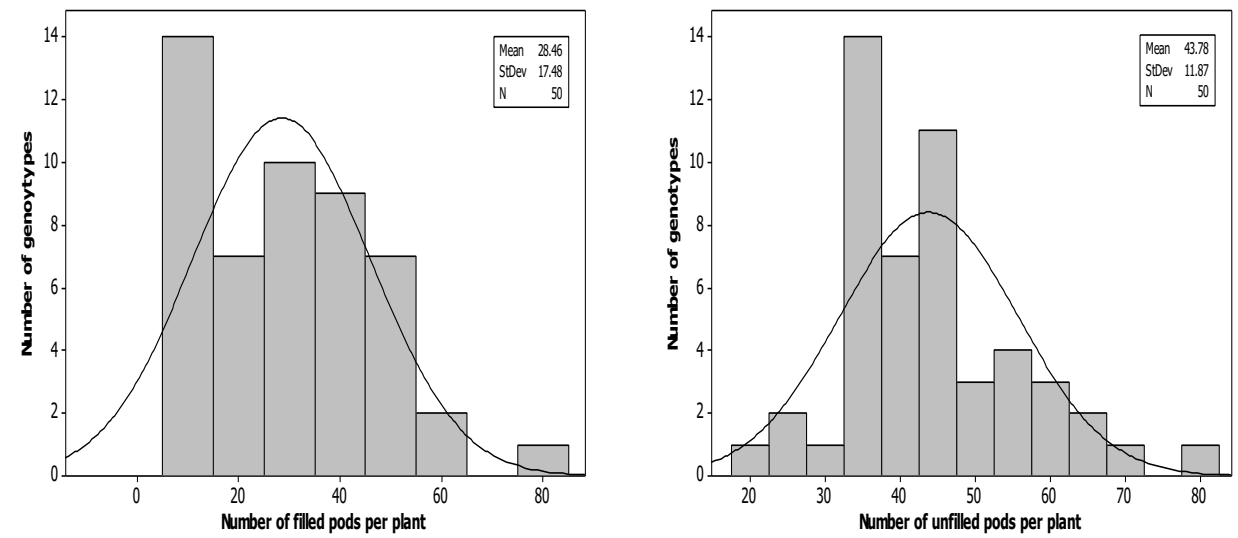

Figure 1. Number of filled pods (left) and unfilled pods (right) per plant of fifty soybean genotypes
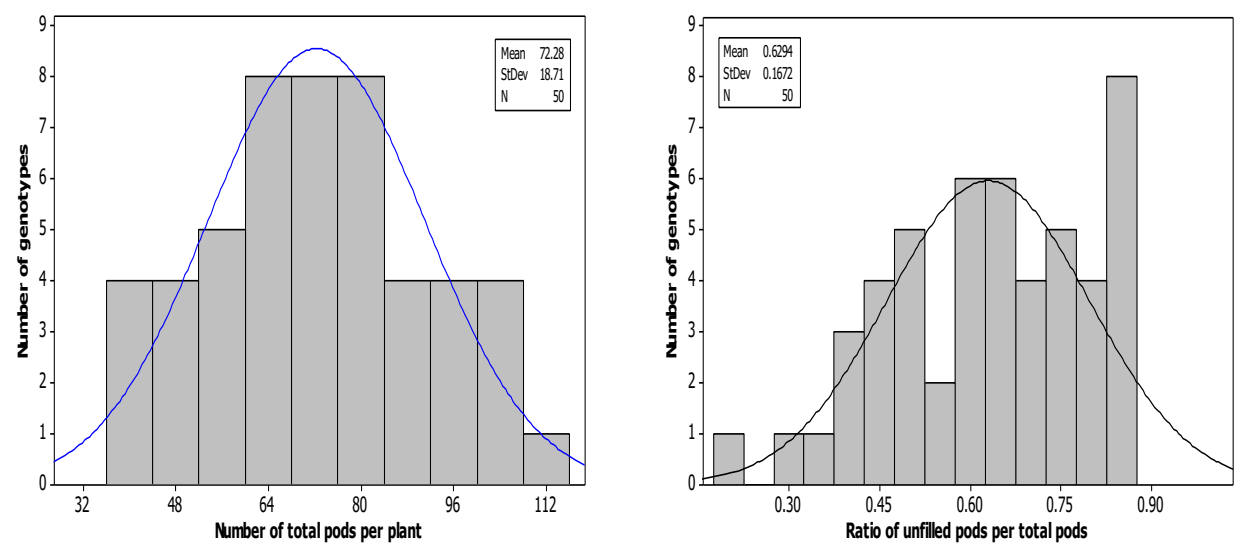

Figure 2. Number of total pods (left) and ratio of unfilled pods (right) to total pods of fifty soybean genotypes 

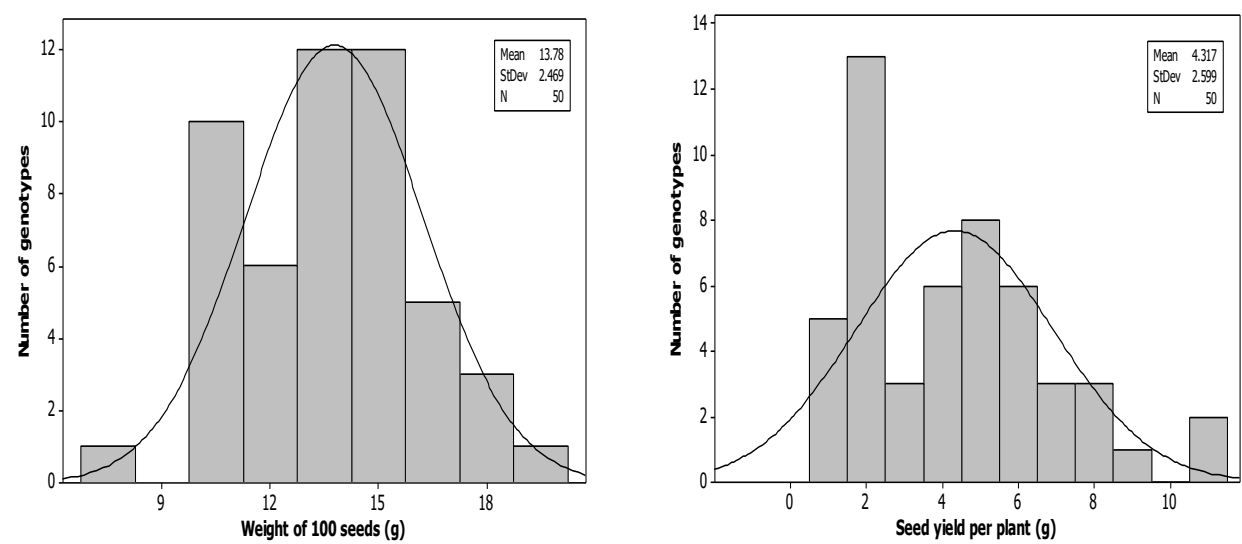

Figure 3. Weight of 100 seeds (left) and seed (right) yield per plants of fifty soybean genotypes

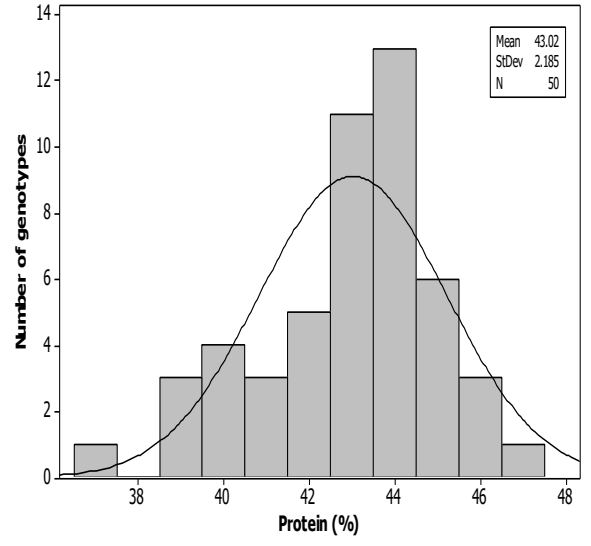

Figure 4. Seed protein content of fifty soybean genotypes

The seed protein content of 50 tested genotypes ranged from $36.82 \%$ to $47.23 \%$. The mean of the protein content for this population was $43.02 \%$. In general, the protein contents were in a class of $33 \%$ and $34 \%$ (Fig. 4). Hwang et al. (2014) reported that a soybean genotype may contain $35-50 \%$ of protein. A protein content of more than $45 \%$ is considered as high. In this study, there were several genotypes with a high protein content, such as MLGG 0164, MLGG 0195, MLGG 0169 and MLGG 0091with protein contents of 47.23, 46.44, 46.32 and $46.00 \%$ respectively. Seed protein content is a quantitative trait controlled by many genes, and the interaction with the environment effects seed protein content (Hwang et al 2014). The proteomic adjustments during seed filling and increasing selective accumulation to maintain normal protein content due to the compensation for shortage of major proteins (Schmidt et al. 2011) are the indication of genes control existence. Interaction between genes and environment is also reflected in the soil nutrient such as nitrogen and sulfur which are involved in the biosynthesis of protein and sulfur-containing amino acids (Yi et al. 2010).

\section{Relationship between protein content and agronomical characters}

The protein content is closely linked with all observed agronomical characters, except the number of unfilled pods per plant (Table 1). Seed protein content can affect soybean agronomical characters in conjunction with the infestation of $N$. viridula. In this study, the characters that can describe causal relationship between the protein content and infestation of $N$. viridula is the number of unfilled pods and the ratio of unfilled pods to total pods. The number of unfilled pods per plant is indicative of the preference of $N$. viridula to a genotype. More the number of unfilled pods, more is the preference of $N$. viridula for that genotype. In this study, as mentioned earlier, there was no correlation between the number of unfilled pods and the seed protein content. There can be two possible explanations for this. The first is that protein is not a substrate atracting $N$. viridula to feed on soybean seeds. The second is that $N$. viridula does not feed on the seeds completely, but only feed partially on small sized seeds. This study corroborates the second possibility because there is a correlation between the weight of 100 seeds and protein content (Table 1). The resistance of soybean genotypes varies from the least infested, low yield reduction, low levels of damage in seeds and low levels of leaf retention (Souza et al. 2016). There are some gene families associated with nucleotidebinding and receptor-like proteins serving in the plant's biotic resistance (McHale et al. 2012). The preference is caused by metabolic processes in the pest showing a pest having different characteristics compared to other pests.

Soybean plant has tolerance mechanism to limit reduction in seed yield (Souza et al. 2016). The ratio of unfilled pods to total pods describes the tolerance of a genotype to $N$. viridula infestation. Therefore, as the ratio of unfilled pods to total pods increases, the tolerance of a genotype against $N$. viridula decreases. In this study, the protein content correlated negatively with the ratio of unfilled pods to total pods. This means that the higher protein content, the lower is the ratio of unfilled pods to total pods. This is also supported by the significant correlation between the number of filled pods and protein content. 
Table 1. Correlation among some agronomical characters and protein contents

\begin{tabular}{|c|c|c|c|c|c|c|}
\hline & Fpod & Upod & Tpod & Rpod & W100 & Yield \\
\hline Protein & $0.422 * *$ & 0.065 & $0.434 * *$ & $-0.399 * *$ & $-0.404 * *$ & $0.317^{*}$ \\
\hline Fpod & & -0.233 & $0.783 * *$ & $-0.943 * *$ & $-0.383 * *$ & $0.938 * *$ \\
\hline Upod & & & $0.421 * *$ & $0.461 * *$ & -0.111 & $-0.312 *$ \\
\hline Tpod & & & & $-0.585 * *$ & $-0.428 * *$ & $0.676 * *$ \\
\hline Rpod & & & & & 0.277 & $-0.928 * *$ \\
\hline W100 & & & & & & -0.124 \\
\hline
\end{tabular}

Fpod $=$ number of filled pods per plant, Upod $=$ number of unfilled pods per plant, Tpod $=$ number of total pods per plant, Rpod $=$ ratio of unfilled pods to total pods per plant, $\mathrm{W} 100=$ weight of 100 seeds $(\mathrm{g})$, Yield $=$ seed yield per plant $(\mathrm{g})$, Protein $=$ protein content of seeds $(\%)$
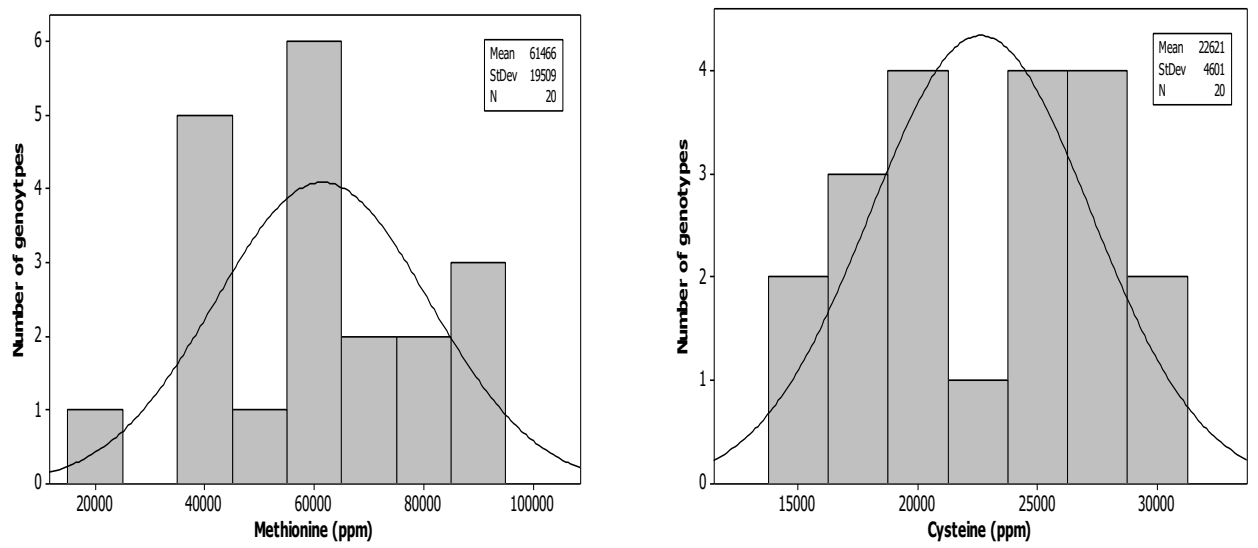

Figure 5. Methionine (left) and cysteine (right) contents of twenty soybean genotypes

\section{Relationship between methionine-cysteine content and agronomical characters}

Protein content has a close relationship with the profile of essential amino acids, such as methionine and cysteine contents (Vaughn et al. 2014). The content of methionine and cysteine was measured in 20 genotypes, which are chosen to represent the entire range of protein content (lowest to highest) of all the 50 genotypes included in this study. Methionine content ranged from 23508 to 91128 ppm with a mean of 61466 ppm (Figure 5). Most genotype had methionine content between 40000 to $60000 \mathrm{ppm}$. Song et al. (2013) reported that methionine content of soybeans varies from $9592 \pm 328$ to $2616 \pm 22340 \mathrm{mmol}$ $\mathrm{g}^{-1}$ fresh weight seed. Certain biosynthesis pathways contribute to seed methionine content (Amir et al. 2012), leading to a complex metabolism originating from multiple gene expression. Three genotypes studied, i.e. MLGG 0196, MLGG 0164, and MLGG 0195, showed methionine contents up to $90000 \mathrm{ppm}$. These three genotypes can be used as source genes for the improvement of methionine content of soybean.

The cysteine content varied between 15112 to 30122 ppm, with the mean value of 22621 ppm (Figure 5). Majority of the tested genotypes showed cysteine content around 22500 ppm. Two genotypes, i.e. MLGG 0896 and
MLGG 0195, had cysteine content of as high as 30000 $\mathrm{ppm}$. Cysteine protease is the primary protease in the gut of $N$. viridula (Lomate and Bonning 2016) due to which $N$. viridula prefer cysteine rich soybeans. The soybeans with higher free cysteine also had a high concentration of Bowman-Birk protease inhibitor, a protein with rich in cysteine (Kim et al. 2012). Bowman-Birk protease inhibitor is also a known anticarcinogenic agent (Kennedy 1998).

Methionine content was significantly correlated with the number of unfilled pods. This fact indicates that increase in methionine content also increases the preference of $N$. viridula. Besides being an important plant nutrient required for the biosynthesis of methionine and cysteine, sulfur can be also metabolized to form molecules which are capable of protecting plants from oxidative and environmental stresses (Yi et al. 2010). The total number of pods, which is a combination of both filled and unfilled pods, were significantly correlated with methionine content (Table 2). As the number of filled pods is not significantly correlated, the greater influence on the correlation was due to the number of unfilled pods. In most cases, a high methionine content correlates with abnormal phenotypes causing yield reduction (Galili and Amir 2013). However, there were no evidences for this report in the present study. 
Table 4. Agronomical performance of five selected soybean genotypes with high protein, methionine and cysteine contents

\begin{tabular}{lccccccccc}
\hline Genotipe & Fpod & Upod & Tpod & Rpod & W100 & Yield & Protein & Methionine & Cysteine \\
\hline MLGG 0164 & 36 & 70 & 106 & 0.66 & 10.69 & 4.21 & 47.23 & 90623.92 & 24782.27 \\
MLGG 0195 & 33 & 55 & 87 & 0.63 & 13.50 & 5.12 & 46.44 & 90341.43 & 29069.35 \\
MLGG 0103 & 48 & 66 & 114 & 0.58 & 10.74 & 6.45 & 45.14 & 84762.43 & 26948.54 \\
MLGG 0896 & 45 & 47 & 92 & 0.51 & 10.17 & 4.70 & 44.84 & 74548.48 & 30122.02 \\
MLGG 0196 & 63 & 37 & 100 & 0.37 & 14.84 & 10.95 & 44.73 & 91127.94 & 26265.43 \\
\hline
\end{tabular}

Note: Fpod = number of filled pods per plant, Upod = number of unfilled pods per plant, Tpod = number of total pods per plant, Rpod = ratio of unfilled pods to total pods per plant, $\mathrm{W} 100=$ weight of 100 seeds $(\mathrm{g})$, Yield $=$ seed yield per plant $(\mathrm{g})$, Protein $=$ protein content $(\% \mathrm{dw})$, Methionine $=$ methionine content $(\mathrm{ppm})$, Cysteine $=$ cysteine content $(\mathrm{ppm})$

Table 2. Correlation of methionine and cysteine contents with agronomical characters

\begin{tabular}{|c|c|c|c|c|c|c|}
\hline & Fpod & pod & Tpod & pod & W100 & Yield \\
\hline & & & & & & \\
\hline & & & & & & \\
\hline \multicolumn{7}{|c|}{$\begin{array}{l}\text { Note: Fpod }=\text { number of filled pods per plant, Upod }=\text { number of } \\
\text { unfilled pods per plant, Tpod }=\text { number of total pods per plant, } \\
\text { Rpod }=\text { ratio of unfilled pods to total pods per plant, W100 }= \\
\text { weight of } 100 \text { seeds }(\mathrm{g}) \text {, Yield }=\text { seed yield per plant }(\mathrm{g}) \text {, } \\
\text { Methionine }=\text { methionine content }(\mathrm{ppm}) \text {, Cysteine }=\text { cysteine } \\
\text { content }(\mathrm{ppm})\end{array}$} \\
\hline
\end{tabular}

Table 3. Correlation of among protein, methionine and cysteine contents

\begin{tabular}{lll}
\hline & Methionine & Cysteine \\
\hline Protein & $0.961^{* *}$ & $0.999^{* *}$ \\
Methionine & & $0.963^{* *}$ \\
\hline
\end{tabular}

The cysteine content shows significant positive correlation with the number of filled pods, total number of total pods and seed yield per plant, but it has significant negative correlation with ratio of unfilled pods to total pods. There was no significant correlation between cysteine content and number of unfilled pods. Phytocystatins has the capability to inhibit heterologous enzymes and serve in plant defense. Decreased pest development and reproduction has been reported in the presence of high phytocystatins (Carrillo et al. 2012).

\section{Relationship among protein, methionine and cysteine contents}

The protein content was significantly correlated with methionine and cysteine contents. Similarly, the methionine content was significantly correlated to the cysteine content (Table 3). Ramamurthy et al. (2014) has also reported the correlation between methionine and cysteine content. This relationship also has a genetic correlation (Carlson 2011) having a high role in a plant breeding program. However, such a positive genetic correlations are not found between protein content and cysteine content (Carlson 2011). During seed development, biosynthetic pathway of cysteine is active, but the supply of cysteine does not affect methionine or protein synthesis
(Tabe et al. 2010). Song et al. (2013) proposed a positive relationship between methionine content and other amino acids synthesis which causes more seed proteins synthesis.

Performance of five genotypes with high biochemical contents

Five genotypes were selected from the 50 studied genotypes, based on their high biochemical contents namely, protein, methionine and cysteine. Their agronomical features and biochemical contents are presented in Table 4. The highest number of total pods was found in MLGG 0164 and MLGG 0196, which produced 106 and 100 pods respectively. However, these two genotypes had a different ratio of unfilled pods to total pods indicating their different tolerance levels against $N$. viridula. MLGG 0196 was more tolerant than MLGG 0164. Methionine and cysteine contents in these two genotypes were almost similar. This observation is not coinciding with the earlier finding that cysteine content has a negative correlation with plant tolerance. This deviation may be due to the presence of some morphological characters of the plant which are limiting the feeding of seeds of MLGG 0196 by $N$. viridula. In this study, however, the morphological characters were not observed. The MLGG 0195 had high protein, methionine and cysteine content. Similar to MLGG 0164, it also had a high ratio of unfilled pods to total pods describing low tolerance to $N$. viridula. The cysteine content in this genotype was similar to MLGG 0896, also having relatively low tolerance.

In conclusion, performance of the agronomical and chemical characters varied among the tested soybean germplasm. Most of the agronomical characters showed significant correlation with protein content. A significant correlation was also found among protein, methionine and cysteine contents. The protein and cysteine contents did not relate to $N$. viridula preference, but related to soybean tolerance against $N$. viridula. It is indicated by the insignificant correlation between protein and cysteine contents with number of unfilled pods, and also the negative correlation between protein and cysteine contents with the ratio of unfilled pods to total pods. Methionine content increased $N$. viridula preference, but had no effect on soybean tolerance to $N$. viridula infestation. Five genotypes, namely MLGG 0164, MLGG 0195, MLGG 0103, MLGG 0896, and MLGG 0196 were selected based on high seed biochemical contents. These genotypes can be used as gene sources in soybean breeding program. Among these five genotypes, MLGG 0195 had high protein, 
methionine and cysteine contents, but it was not tolerant to $N$. viridula. Hence, this genotype should be cultivated by controlling $N$. viridula optimally. MLGG 0196 had the highest methionine content, relatively high cysteine content, and it was also tolerant to $N$. viridula. This genotype can be used in breeding programs to improve seed biochemical contents and soybean plant's tolerance against $N$. viridula.

\section{ACKNOWLEDGEMENTS}

This study was funded by the Ministry of Research and Higher Education through the scheme of INSINAS 2016 with Contract no. 280/SP2H/LT/DRPM/III/2016. We also thank Mrs. Lina Kusumawati for her assistance in protein analysis.

\section{REFERENCES}

Amir R, Han T, Ma F. 2012. Bioengineering approaches to improve the nutritional values of seeds by increasing their methionine content 29(4): 915-924. https://link.springer.com/article/10.1007/s11032-011-9690-7

AOAC. 2005. Microchemical determination of nitrogen using micro Kjeldhal method (12.1.07). Official Methods of Analysis of AOAC International. Vol. I. Agricultural Chemicals, Contaminants, Drugs Gaithersburs, Maryland, USA: AOAC International.

Ball RO, Courtney-Martin G, Pencharz PB. 2006. The in vivo sparing of methionine by cysteine in sulfur amino acid requirements in animal models and adult humans. J Nut 136(6):1682S-1693S

BPS. 2017. Average per Capita Consumption per Week of Several Kinds of Important Foodstuffs, 2007-2015. Badan Pusat Statistik https://www.bps.go.id/LinkTabelStatis/view/id/950 (Accesed 5 April 2017). [Indonesian].

Carlson CM. 2011. Genetic Control of Protein and Amino Acid Content in Soybean Determined in Two Genetically Connected Populations [Disertation]. North Carolina State University. https://repository.lib.ncsu.edu/bitstream/handle/1840.16/10184/etd.pd $\mathrm{f} ;$ sequence $=2$

Carrillo L., Martinez M., Ramessar K., Cambra I., Castañera P., Ortego F., Díaz I. 2012. Expression of a barley cystatin gene in maize enhances resistance against phytophagous mites by altering their cysteineproteases. Plant Cell Rep 30(1): 101-112. doi: 10.1007/s00299-0100948-z

Corrêa-Ferreira BS, De Azevedo J. 2002. Soybean seed damage by different species of stink bugs. Agric and For Entomol 4: 145-150. http://onlinelibrary.wiley.com/doi/10.1046/j.14619563.2002.00136.x/pdf

Galili G, Amir R. 2013. Fortifying plants with the essential amino acids lysine and methionine to improve nutritional quality. Plant Biotechnol J 11: 211-222. doi: 10.1111/pbi.12025

Ge Y, Liu P., Yang R., Zhang L, Chen H., Camara I, Liu Y, Shi W. 2015. Insecticidal constituents and activity of alkaloids from Cynanchum mongolicum. Molecules 20: 17483-17492. doi: 10.3390/molecules200917483

Giacometti R, Barneto J, Barriga LG, Sardoy PM, Balestrasse K, Andrade AM, Pagano EA, Alemano SG, Zavala JA. 2016. Early perception of stink bug damage in developing seeds of field-grown soybean induces chemical defences and reduces bug attack. Pest Manag Sci 72(8) 1585-1594. doi: $10.1002 / \mathrm{ps} .4192$

Gupta P, Singh R, Malhotra S, Boora KS, Singal HR. 2010. Characterization of seed storage proteins in high protein genotypes of cowpea [Vigna unguiculata (L.) Walp.]. Physiol Mol Biol Plants, 16(1): 53-58. doi: 10.1007/s12298-010-0007-9

Hartweck L, Cardona C, Osborn T. 1997. Bruchid resistance of common bean lines having an altered seed protein composition. Theor App Genet 95: 1018-1123. doi: 10.1007/s001220050

Hwang E, Song Q, Jia G, Specht JE, Hyten DL, Costa J, Cregan PB. 2014. A genome-wide association study of seed protein and oil content in soybean. BMC Genomics 15:1. DOI: 10.1186/1471-2164-15-1
Islam AKMS, Nath UK, Rai PK, Rahman MM, Haque MA, Rahman MA. 2016. Genetic study and selection of soybean lines for higher yield. Inter J Biosci 8(2): 209-217. doi: 10.1186/1471-2164-15-1

Karley AJ, Douglas AE, Parker WE. 2002. Amino acid composition and nutritional quality of potato leaf phloem sap for aphids. J Exp Biol 205: 3009-3018.

Kementan 2015. Outlook for Food Crop Agricultural Commodities: Soybeans. Agricultural Data Center and Information System. Kementerian Pertanian, Jakarta. [Indonesian].

Kennedy AR. 1998. The Bowman-Birk inhibitor from soybeans as an anticarcinogenic agent. Am J Clin Nutr. 68(6 Suppl):1406S-1412S. doi: 10.1093/ajcn/68.6.1406S.

Kim GS, Weiss SJ, Levine RL. 2014. Methionine oxidation and reduction in proteins. Biochimica et Biophysica Acta 1840(2): 901-905. doi: 10.1016/j.bbagen.2013.04.038

Kim WS, Chronis D, Juergens M, Schroeder AC, Hyun SW, Jez JM, Krishnan HB. 2012. Transgenic soybean plants overexpressing Oacetylserine sulfhydrylase accumulate enhanced levels of cysteine and Bowman-Birk protease inhibitor in seeds. Planta 235(1): 13-23. doi: 10.1007/s00425-011-1487-8

Kuswantoro H. 2015. Agronomical characters of some soybean germplasm under waterlogging condition. J Agron 14(2): 93-97. doi: 10.3923/ja.2015.93.97

Kuswantoro H. 2016. Potential yield of acid-adaptive soybean promising lines in ultisols of Tanah Laut Regency, South Kalimantan Province, Indonesia. Biotropia 23(1): 52-57. doi: 10.11598/btb.2016.23.1.561

Kuswantoro H. 2017. Genetic variability and heritability of acid-adaptive soybean promising lines. Biodiversitas 18(1): 378-382. doi: 10.13057/biodiv/d180149

Lomate P.R., Bonning B.C. 2016. Distinct properties of proteases and nucleases in the gut, salivary gland and saliva of southern green stink bug, Nezara viridula. Sci Rep 6; Article number: 27587. doi: $10.1038 /$ srep 27587

Malek MA, Rafii MY, Afroz MSS, Nath UK, Mondal MMA. 2014. "Morphological characterization and assessment of genetic variability, character association, and divergence in soybean mutants. The Sci World J, Article ID 968796, 12 pages, 2014. doi:10.1155/2014/968796

Malik S. 2014. Genetic variability for qualitative and quantitative traits and molecular marker studies in Glycine soja derived lines of soybean [Thesis]. University of Agriculture and Technology, Pantnagar. http://krishikosh.egranth.ac.in/handle/1/67528

McHale LK, Haun WJ, Xu WW, Bhaskar PB, Anderson JE, Hyten DL, Gerhardt DJ, Jeddeloh JA, Stupar RM. 2012. Structural variants in the soybean genome localize to clusters of biotic stress-response genes. Plant Physiol 159: 1295-1308. doi: 10.1104/pp.112.194605

Ministry of Agriculture. 2015. Outlook for Agricultural Commodities of Food Crops: Soybean. Center of Data and Information of Agriculture. Ministry of Agriculture, Jakarta. [Indonesian]

Minney BHP, Gatehouse AMR, Dobie P, Dendy J, Cardona C, Gatehouse JA. 1990. Biochemical bases of seed resistance to Zabrotes subfasciatus (bean weevil) in Phaseolus vulgaris (common bean); a mechanism for arcelin toxicity. J Insect Physiol 36(10): 757-767. doi: 10.1016/0022-1910(90)90049-L

Moreno A, Garso E, Fernandez-Mata G, Kassem M, Aranda MA, Fereres A. 2011. Aphids secrete watery saliva into plant tissues from the onset of stylet penetration. Entomologia Experimentalis et Applicata 139(2): 145-153. doi: 10.1111/j.1570-7458.2011.01117.x

Naik S.M., Madhusudan K., Motagi B.N., Nadaf H.L., Rao M.S.L., Mugali S., Gurumuthy R., Basavaraj G.T. 2016. Genetic variability and association studies for seed yield and longevity with component traits in soybean [Glycine $\max$ (L.) Merill.]. Ecol Environ Conser Paper 22: 117-122.

Ramamurthy RK, Jedlicka J, Graef GL, Waters BM. 2014. Identification of new QTLs for seed mineral, cysteine, and methionine concentrations in soybean [Glycine $\max$ (L.) Merr.]. Mol Breed 34(2): 431-445.

Rohman A, Gandjar IG. 2007. Chromatography Method for Food Analysis. Pustaka Pelajar. Yogyakarta. [Indonesian].

Ryan CA. 1990. Protease inhibitors in plants: genes for improving defenses against insects and pathogens. Ann Rev Phytopathol 28: 425-449. doi: 10.1146/annurev.py.28.090190.002233

Schmidt MA, Barbazuk WB, Sandford M, May G, Song Z, Zhou W, Nikolau BJ, Herman EM. 2011. Silencing of soybean seed storage proteins results in a rebalanced protein composition preserving seed protein content without major collateral changes in the metabolome 
and transcriptome. Plant Physiol 156: 330-345. doi: 10.1104/pp.111.173807

Song S, Hou W, Godo I, Wu C, Yu Y, Matityahu I, Hacham Y, Sun S, Han T, Amir R. 2013. Soybean seeds expressing feedback-insensitive cystathionine $\gamma$-synthase exhibit a higher content of methionine. J Exp Bot, 64(7): 1917-1926. doi: 10.1093/jxb/ert053

Souza ES, Silva JPGF, Baldin ELL, Pierozzi CG, Cunha LS, Canassa VF, Pannuti LER, Lourenção AL. 2016. Response of soybean genotypes challenged by a stink bug complex (Hemiptera: Pentatomidae). J Econ Entomol 109(2): 898-906.

Tabe L, Wirtz M, Molvig L, Droux M, Hell R. 2010. Overexpression of serine acetlytransferase produced large increases in O-acetylserine and free cysteine in developing seeds of a grain legume. J Exp Bot 61(3): 721-733. doi: 10.1093/jxb/erp338

Vaughn JN, Nelson RL, Song Q, Cregan PB, Li Z. 2014. The genetic architecture of seed composition in soybean is refined by genomewide association scans across multiple populations. Gen Genom Genet 4(11): 2283-2294. doi: 10.1534/g3.114.013433

Waters System Guide 2012. Waters aquity UPLC H Class and H Class bio amino acid analysis system guide. USA

Wu G. 2013. Functional amino acids in nutrition and health. Amino Acids 45: 407-411. doi: 10.1534/g3.114.013433.

Yi H, Ravilious GE, Galant A, Krishnan HB, Jez JM. 2010. From sulfur to homoglutathione: thiol metabolism in soybean. Amino Acids 39(4): 963-978. doi: 10.1007/s00726-010-0572-9 